\title{
Rules of Origin in ASEAN+1 Free Trade Agreements on Agriculture Commodity
}

\author{
Miranda Febriningtyas ${ }^{1}$, Rina Oktaviani² ${ }^{2}$ Amzul Rifin ${ }^{3}$
}

\begin{abstract}
Abstrak
Rules of origin that indirectly serve as trade barriers, thus raising the potential for increased production costs. In agricultural commodities, the rules of origin are primarily determined by wholly-obtained, so the potential for more significant increases in the cost of agricultural products versus other commodities. The purpose of this paper is to compare the restrictiveness index rules of origin in ASEAN + 1 FTAs (ACFTA, AJCEP, and AKFTA) on agricultural commodities. This study uses the Regime Wide Harris Index by Kelleher to calculate the restrictiveness level rules of origin in ASEAN + 1 FTAs. Based on product-specific regulations, AJCEP has the most flexible rules of origin, followed by AKFTA and ACFTA as the most restrictive of origin in ASEAN + 1 FTAs. In the Regime Wide Harris Index, the results show that AJCEP has a flexible origin rule after AKFTA, and ACFTA is the most strict rules of origin in ASEAN + 1 FTAs. These results are influenced by the most substantial diagonal side cumulation in the ACFTA.
\end{abstract}

Keywords: rules of origin, agriculture commodity, ASEAN+1, restrictiveness index

\begin{abstract}
Abstrak
Rules of origin yang secara tidak langsung berperan sebagai hambatan perdagangan sehingga menimbulkan potensi peningkatan biaya produksi. Pada komoditas pertanian, rules of origin yang ditetapkan sebagian besar wholly obtained sehingga potensi peningkatan biaya lebih besar pada komoditas pertanian dibandingkan komoditas lain. Tujuan dari makalah ini adalah membandingkan indeks hambatan rules of origin di ASEAN+1 FTAs (ACFTA, AJCEP dan AKFTA) pada komoditas pertanian. Penelitian ini menggunakan Regime Wide Indeks Harris oleh Kelleher untuk menghitung tingkat hambatan rules of origin pada ASEAN+1 FTAs. Berdasarkan Product Specific Rules, AJCEP memiliki rules of origin paling fleksibel, diikuti dengan AKFTA dan ACFTA sebagai aturan asal yang paling ketat di ASEAN+1 FTAs. Pada Regime Wide Harris Index didapatkan hasil bahwa AJCEP memiliki aturan asal yang fleksibel setelah AKFTA, dan ACFTA merupakan rules of origin yang paling ketat di ASEAN+1 FTAs. Hasil ini dipengarubi oleh sisi diagonal cummulation yang paling besar di ACFTA.
\end{abstract}

Kata Kunci: rules of origin, komoditas pertanian, ASEAN+1, indeks hambatan

How to Cite:

Febriningtyas, M., Oktaviani, R., \& Rifin, A. (2018). Rules of Origin in ASEAN+1 Free Trade Agreements on Agricultural Commodity. Signifikan: Jurnal Ilmu Ekonomi. Vol. 7 (1): 15 - 26. doi: http//dx.doi.org/10.15408/ sjie.v7i1.6432 


\section{Introduction}

Free Trade Agreement (FTA) has increased since the form of the World Trade Organization (WTO) replaces the role of General Agreement on Tariffs and Trade (GATT) in 1995. The concept of economic integration that leads to free trade agreements characterized by the emergence of various massive forms of multilateral, regional and bilateral. As of 15 June 2014, there are 379 regional agreements according to WTO. The formation of North American Free Trade Agreement (NAFTA), European Union (EU), Asia Pacific Economic Cooperation (APEC) and ASEAN Free Trade Agreement (AFTA) are the examples of the establishment of the RTA because nations want consolidation to protect themselves. ASEAN, which initially conducted FTA limited to AFTA, began to develop into ASEAN + 1 (Japan, South Korea, and China) which is the country's biggest trading partner of The Association of South East Asian Nations (ASEAN).

The large number of FTAs from these proliferations gives rise to the term "noodle bowl problem." Each FTA has its own rules, details, and interests within a region, which a country may engage in more than one FTA. It is not uncommon; then an item is produced with materials originating from two or more countries or even countries that originate outside the FTA concerned. So it becomes difficult to determine the "origin" of a good (Harris, 2007). Automotive may manufacture and assemble in a country, but some parts may be taken and manufactured in other countries. At the same time, the determination of tariffs on imported goods increasingly decentralized due to the current process of production and international trade that rates different tariffs on goods produced in different countries. The rules of origin come as a set of rules that determine the origin of products.

Rules of Origin ( $\mathrm{RoO}$ ) defined as the number of criteria used to determine the country or region of origin of a good or service in international trade agreement (Harris, 2007). Rules of origin are used to prevent the occurrence of trade deflections to avoid tariff payments to countries with lower tariffs and by importing countries doing little value added or added value, or even none at all, which is then traded by saying as a local product of the country importer. In free trade agreements, RoO prevents imports from non-member countries from entering free trade areas through countries (trade deflection). For example three countries the EU, Morocco, and Poland, where the EU and Morocco have signed a bilateral free trade agreement. $\mathrm{RoO}$ is needed to prevent a trade deflection, to ensure export goods to Morocco via the EU. RoO determination of final goods being more complicated if intermediate goods require products from other countries to become finished goods rather than before. Therefore, when Morocco imports intermediaries from Poland which then used in the production of final goods exported to the EU, RoO is then asked to determine whether an end product is considered to be initially from Morocco or not. Usually, there are three criteria are used in determining the origin status of a product, such as: first, whether the transformation of a finished good, included in a different tariff classification line or can be called a Change Tariff Classification. Second, whether the value of imports or goods semi-finished exceeds a certain percentage (mostly 40\%) of the total finished products or can be called RVC (Regional Value Contain). Third, whether a particular production process requires a specific process of production or not. RoO determines which of these combinations applied to each 
product (Augier et al. 2005). All ASEAN + 1 FTAs -such as: ASEAN-China Free Trade Agreement (ACFTA), ASEAN-Kore Free Trade Agreement (AKFTA), and ASEAN-Japan Comprehensive Economic Partnership (AJCEP)- adopt a 40\% general rule of local material (RVC), with full accumulation. The FTA also provides alternative rules by using CTC for a particular product. For AJCEP, the general rule is CTC, with the adoption of RVC more considered an optional standard. This AJCEP rule reflects a more liberal RoO tendency for Japan when compared to the relatively complex RoO (example JSEPA) (Medalla 2009).

For agricultural and food products in ASEAN + 1 FTA, most of them use the wholly obtained regulations and Regional Value Content (RVC), also referred to as regional valueadded needs, in general by $40 \%$. AKFTA is the most liberal for the food and agriculture sector since 23 of HS in these agricultural commodities mostly use RVC rules instead of WO rules. It is contrasted with ACFTA that uses almost entirely RVC (40) and AJCEP regulations that mostly use tariff classification (CTC) changes in agricultural and food products (Medalla 2009).

RoO determination on products that have many components to finished goods, more difficult when compared with agricultural products. Most agricultural products, have $\mathrm{RoO}$ rules that fully produced, planted or raised in the country or commonly referred to as wholly obtained rules. However, the RoO rules are so necessitating; it makes the potential in production costs to increase (Anson et al. 2005). Not all factors of production can be obtained in a country, especially when it comes to the costs incurred to acquire these factors of production. So the strict determination of $\mathrm{RoO}$ for agricultural products, more likely to increase production costs when compared with other types of products. Indonesia's comparative advantage in the agricultural sector, make the work of Roo backfired. RoO that can be indirectly referred as protection will be delayed and may reduce the benefits that Indonesia may receive from the agricultural sector (Bourdon 2016).

Estevadeordal (2000) who first developed the basic framework of coding for Product specific rules by comparison. Product specific rules in the form of rules hen changed in ordinal index restrictions for more straightforward analysis. Estevadeordal (2000) used this approach to applied in the study of the NAFTA agreement between the US, Canada, and Mexico. Then some writings implement the method of Estevadeordal to the analysis of descriptive contracts, among others Estevadeordal and Suominen (2006), Sanguinetti (2006), Cadot, Estevadeordal, and Suwa-Eisenman (2006), and Suominen (2004). Cadot et al. (2005) used the methodology as used by Estevadeordal (2000) but with similar modifications, but not as widely described previously. The use of ordinal index by Estevadeordal (2000), then developed by Productivity Commission (2004), Anson et al. (2005), Harris (2007) and Kelleher (2011).

Most existing studies are dealing with the impact of rules of origin on trade. In this paper, we are interested in comparing and analyzing the restrictiveness level rules of origin in ASEAN+1 FTAs to find out how much impact the regulation can have on trade. Few studies are providing the assessment of the restrictiveness index rules of origin in ASEAN+1, and among them very little differentiate trade in an agricultural commodity. To our knowledge, there is no existing study analyzing the role of rules of origin which focuses on agricultural commodities in Indonesia. 


\section{Method}

The analysis in this research was conducted by Kelleher (2012) method with the ordinal index for product-specific rules by Harris (2007), to determine the level of restrictive of a $\mathrm{RoO}$ applied by free trade agreement ASEAN +1 on agricultural commodities. To examine the effect of $\mathrm{RoO}$, an index used which aims to capture the restrictions caused by the RoO of each ASEAN + 1 agreement. Agreements analyzed in this study include ACFTA, AKFTA, and AJCEP due to data limitations. The difficulties faced by measuring the level of $\mathrm{RoO}$ restrictions in a regional trade that in reality, this rule more or less expressed in the form of complex legal texts. Thus, to give statistical significance to this rule, they must first be codified. Then the ordinal restriction index must be defined, which summarizes all information as a first step.

Table 1. Restrictiveness Points

\begin{tabular}{|c|c|}
\hline \multicolumn{2}{|l|}{ Change of classification points } \\
\hline Change Item & +2 \\
\hline Change Subheading & +4 \\
\hline Change Heading & +6 \\
\hline Change Chapter & +8 \\
\hline Change Subheading/Change Heading w/Al & +2 \\
\hline \multicolumn{2}{|l|}{ Exception Points } \\
\hline Ex Item & +4 \\
\hline >ex Item and $\leq$ ex Subheading & +5 \\
\hline >ex Subheading and $\leq$ ex Heading & +6 \\
\hline >ex Heading and $\leq$ ex Chapter & +7 \\
\hline >exChapter & +8 \\
\hline \multicolumn{2}{|l|}{ Addition Points } \\
\hline Add Item & -5 \\
\hline >add Item and $\leq$ add Subheading & -6 \\
\hline >add Subheading and $\leq$ add Heading & -7 \\
\hline >add Heading and < add Chapter & -8 \\
\hline add without CC & +8 \\
\hline \multicolumn{2}{|l|}{ Value Test Point } \\
\hline$>0 \%$ and $\leq 40 \%$ & +5 \\
\hline$>40 \%$ and $\leq 50 \%$ & +6 \\
\hline$>50 \%$ and $\leq 60 \%$ & +7 \\
\hline
\end{tabular}

Source: Harris (2007)

Such an approach has introduced by Estevadeordal (2000) proposing synthetic indexes at the tariff line level, ranging from one (least restrictive) to seven (strictest), based on observational rules that summarize RoO Estevadeordal (2000) on NAFTA (Bourdon 2016). 
This categorization adopts the method, or test, of the ROO examined by the World Customs Organization (WCO), and regulations that have evolved to support the application of such tests. This index continuously developed by Australia's Productivity Commission (2004), Anson et al. (2005), and Harris (2007). Most agricultural, plant or animal products, examined further in this paper, are subject to Wholly Obtained (WO) regulations or as a whole produced by a particular country. Finally, the technical requirements (TECH) became the foundation for further regulations on ROO (Chase 2007). Harris (2007) uses a point system for different regulatory forms that allow mapping to be an ordinal indicator of restrictions. These points added or subtracted based on the elements used in the rule definition. Giving points are summarized as follows in Table 1 (Harris 2007).

The method developed by Harris (2007) focuses more on product-specific rules and excludes information on the broader terms of the agreement. Kelleher (2012) weighted the Harris index (2007) with more broad terms in the regime wide accumulation zone, de minimis and certificate of origin. Larger cumulation zones have higher likelihood to produce more efficient input producers and have an impact on production decisions by limiting permissible access to low-cost inputs from third countries. Thus, the primary determinant of the RoO restriction index is the possibility that producers can produce a product with low input costs from large accumulation zones. De minimis involves relief on the change of tariff classification or technical criteria by facilitating a product manufactured with input not derived from a member of an FTA. Usually, the de minimis level on agricultural products is less when compared to the overall de minimis level. In the Certificate of Origin, the more administrative stages necessary to confirm the status of origin, the higher the cost of $\mathrm{RoO}$ and the lower the incentive to apply preferential treatment.

$R O O_{j t}=\left\{\right.$ ROO Indeks $\left._{k}\left[1-\frac{\sum G D P_{j t} \text { Country }}{\sum G D P_{t} \text { Cumulation Zone }}\right] \times\left[\frac{100-\text { de minimis }_{j}}{100}\right]\right\}+$ Cert $_{i j} \ldots \ldots \ldots(1)$

$\mathrm{RoO}_{i t}$ is the RoO Index of country $\mathrm{i}$ in year $\mathrm{t}$, RoO PSRO is the ordinal product specific rules of RoO ASEAN + 1 by Harris (2007), GDP it Country is the real GDP of country $\mathrm{i}$ in year $\mathrm{t}, \mathrm{GDP}_{\mathrm{t}}$ Cumulation zone is the real GDP of member countries agreement in a free trade agreement in year $t$, De minimis represents the maximum level of material not originating from country i permitted before the last item of origin status in year $\mathrm{t}$, $\mathrm{Cert}_{\mathrm{it}}$ shall be assigned a value of 1 if country i applies certificate of origin to all goods originating from his country and a value of 0 if not.

\section{Result and Discussion}

The RoO combination on each FTA provides a challenge for the most rigorous comparison of RoOs, plus the FTAs that are in the same region as the ASEAN + 1 FTA. This paper attempts to draw comparisons through the Harris (2007) categorical index based on product-specific rules of a particular RoO type. Assessment of index points is expected to illustrate, as an indicator of how much it demands a RoO for exporters (Estevadeordal, 2000). The observation rules based on the following assumptions: first, Changes at the chapter level are more restrictive when compared to changes in the heading level, subheading so on; second, RVC and TECH attached to product specific rules details will increase ROO 
restrictiveness level. The complete coding is presented in the appendix and briefly shown in Table 2.

The type of ROO used in ASEAN + 1 FTAs on agricultural commodities uses CTC and WO regulations. This fact illustrated that agricultural commodities themselves are fully grown and harvested in certain countries before being processed further (Wholly Obtained). In contrast to other commodities that require other inputs that may not come from a particular country within the same FTA. The CTC rule requires that any material not derived from a country, used in the production of goods shall comply with the requirements of the product. AJCEP mostly uses CC and CC except for rules when compared to ACFTA and AKFTA. This shows that AJCEP is more flexible regarding production requirements to meet RoO than ACFTA and AKFTA. Some AJCEP products that use CC rules include HS 01 Live animals; HS 03 Fish Crustaceans and HS 05 Products of animal origin. HS 09 Coffee, tea, mate \& spices added RVC rules (40), which is the percentage of content needed to qualify origin by 40 percent of total content.

Table 2. RoO Frequency for Agricultural Sector

\begin{tabular}{lccc}
\hline ROO Type & AKFTA & ACFTA & AJCEP \\
\hline WO & 136 & & \\
WO from any ASEAN+1 FTA party or RVC (45) & 2 & 1 & 252 \\
CC & & & 84 \\
CC except from chapter 1 & 2 & & \\
CTH & 9 & & 4 \\
CTSH & 12 & 226 & 2 \\
RVC(40) & 183 & & \\
CTH + RVC & & 5 & \\
CC or RVC(40) & 342 & 342 & 342 \\
Total agricultural commodity & & & \\
\hline
\end{tabular}

Source: Author's Calculation

ACFTA is the most widely used RVC rule (40). There are two methods for calculating RVC (40), the transaction value method and the net cost method. The transaction value method estimates the value of the non-heated material as a percentage of the transaction value. The net cost method calculates the regional value content as part of the net cost incurred by the manufacturer minus costs for sales promotion, royalties, shipping, and packing. Content percentage of 40 percent means to meet the content to be able to qualify origin required by 40 percent of the total existing content.

AKFTA has the most excellent variety of regulations when compared to AJCEP and ACFTA. AKFTA most use the rules of CTH + RVC and WO. WO as described, that production must raise, planted, produced entirely in a particular country to obtain the status of origin. Commodities in AKFTA using WO rules include HS 07 Edible Vegetables; HS 08 
Edible fruits \& nuts, peel of citrus; and HS 10 Bowls of cereal. CTH + RVC provides the greatest regulatory loosely, as it uses the rate change rules at Headings level with additional content from outside the FTA to be able to fulfill the origin status.

Based on the RoO Index analysis in Table 3, at a glance with some exceptions, the RoO restriction level on each FTA has almost similar index values, and the overall index of limitations for the agricultural sector is higher than the overall restriction. This is due to the cumulation zone agreement is quite large from the member countries of the agreement which is a big country (Japan, South Korea, and China). These big countries tend to protect their domestic products more stringently when compared to developing countries (Bourdon, 2016). So the level of restriction becomes greater when compared with other products. Table 3 shows that ACFTA has the highest level of $\mathrm{RoO}$ restriction when compared to other agreements, followed by AKFTA and AJCEP. The results in the table are by the hypothesis stated earlier that earlier agreements have higher levels of restriction when compared to more recent agreements (ACFTA effectively implemented in 2004, AKFTA in 2007 and AJCEP in 2008 ).

Since China decided to join the WTO and do ACFTA agreement, trade between China and ASEAN increased rapidly. China's domestic market is becoming increasingly important on agricultural exports in ASEAN by occupying the third position for export markets for agricultural products. The integration of both economies also provides opportunities for other agricultural exporting countries to increase their exports to China and ASEAN. ACFTA will enhance the competitiveness of its member countries in many commodities. Agriculture alone is an important industry in China that employs over 300 million farmers, which feeds 20 percent of the world's total population despite only 9 percent of the world's fertile land (Carter, 2011). China produces 18 percent of the world's cereal grains, 29 percent of the world's meat, and 50 percent of the world's vegetables. The success of China which is the world's largest agricultural producer as a global producer of pork, wheat, rice, tea, cotton, and fish. The value of China's agricultural output is twice the total value of US output (Carter, 2011).

Through the Early Harvest Program (EHP) in 2004, ACFTA has reduced tariffs for products from HS 01-08 with a maximum tariff rate of 10 percent covering agricultural products, among others, live animals, meat and edible meat offal, fish, dairy products, live trees, vegetables and edible fruits and nuts. The EHP applies to agricultural products, with applicable rules of origin rule of wholly obtained and local content of 40 percent (Tambunan, 2007). This regulation provides an overview of the large level of RoO restrictions, as it requires that good is fully produced in that country or meet a minimum of 40 percent regional added value originating from the country concerned. This strict enforcement of RoO must meet so that agricultural commodities within the scope of EHP get the tariff preferences set. The EHP and RoO programs are quite strictly indirectly used to protect countries with comparative advantages in agriculture, in this case, China, and Indonesia. RoO on HS04 in dairy products strictly applied to ACFTA, given that China is sensitive enough for dairy products. China in 2008 had experienced melanin contaminated milk scandal plus in 2010 there was a case of the presence of a chemical in the dairy products in China. China's desire 
to strengthen the rules for dairy products requires that dairy products come from certain technical originated countries with a certificate of analysis from China itself.

Table 3 Estimation result of Regime Wide Harris Index ASEAN+1 FTAs on agricultural commodities HS 01-14 year 2006-2015

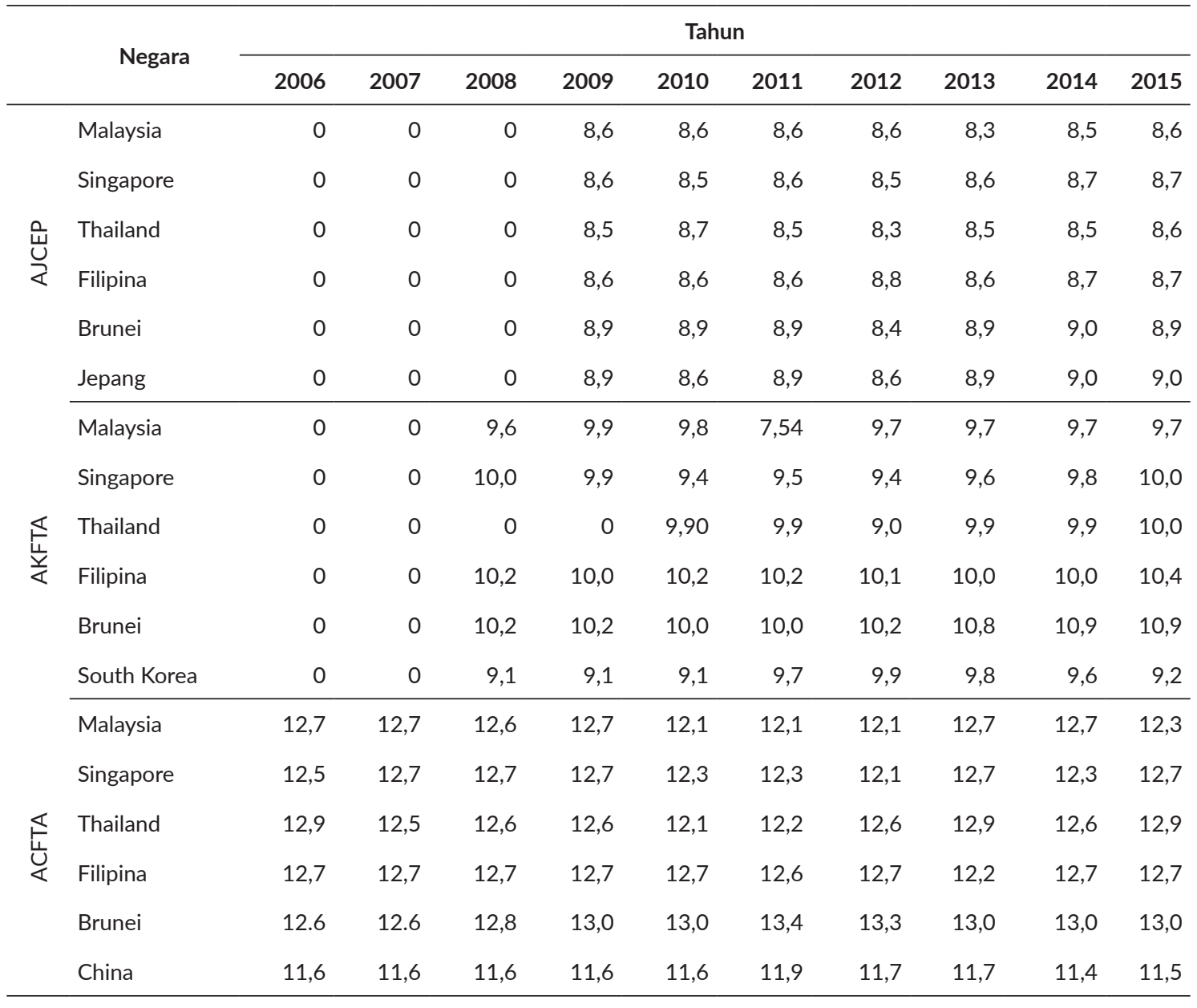

AKFTA appears to be more liberal when compared to ACFTA, with more significant product coverage using changes in tariff classification (Change Tariff Classification). This more liberal $\mathrm{RoO}$ allows the regulation of tariff changes on an item that may use material from another country outside the FTA, from its change from raw goods to finished goods. So a product, may not be fully produced by the country concerned but still meet the rules for tariff preference, AKFTA also introduces an approach to back-to-back certificate of origin for goods through indirect export or in example exports transit at Singapore from other ASEAN countries (Manchin and Pelksman-Balaoing 2007). Based on the specific product type, the AKFTA is longer in the commodity of HS 03 crab crustaceans, mollusks and other water invertebrates, HS 04 Dairy, HS 09 Coffee, tea and spices, HS 11 Industrial milling products, HS 13 Lac, gums, resins and saps and other vegetable extracts. By the low import tariffs on these sectors, and significant trade barriers including regulatory and sanitary constraints even for South Korea itself emphasize agricultural policy, with high food costs for consumers. These restrictions make export products from WTO member countries. 
AJCEP RoO general rule is the change of tariff classification (CTC) with the application of regional added value (RVC) as an optional rule. This illustrates Japan's more liberal RoO tendency from the previous Japanese FTA. Among other countries in northeastern Asia (China, South Korea, and Japan), Japan is the most active country in establishing bilateral agreements with ASEAN countries. This dual track approach is an opportunity for a country to demand more flexible requirements from Japan than in a group negotiation (AJCEP). This makes AJCEP mainly a series of bilateral agreements also between Japan and ASEAN members. So RoO rules become uniform per product and produce a more liberal RoO (Medalla 2009). In previous Japan Bilateral agreements with ASEAN member countries, $\mathrm{RoO}$ has been quite strict for specific products because Japan is essentially a country that is sensitive to agricultural products. Thailand, as the world's largest rice exporter, agreed with Japan not to include rice from FTA with Japan, while the Philippines continues negotiations on the abolition of sugar tariffs. Japanese and Malaysian relations also exclude pineapple and dairy products from Malaysia (Heng 2007).

Previous index methodologies have been applied to analyze NAFTA Roo and EU agreements (Estevadeoral 2000, Brenton and Manchin 2002, Augier, Lai-Tong and Gasiorek 2003, Estevadeordal and Suominen 2003). The index developed in their study has focused on specific RoO provisions - for example, whether the change in tariff classification (CTC) is at a tariff option (HS 8 digits), sub-title (6 digits), toward (4 digits) or chapter (2 digits) level. But some research focuses on the impact of RoO but only on its effects on aggregate exports and does not focus on a particular sector. Estevadeordal (2000) identified that RoO for intermediates is stricter than final goods. and Anson et al. (2005) conclude that the presence of RoO virtually limits the market access that these preferential trading agreements (PTAs) confer to the Southern partners.

\section{Conclusion}

The result of the analysis of the level of restriction shows the level of RoO ACFTA restriction to be the largest in agricultural commodities when compared to other FTAs within the scope of ASEAN + 1. However, if viewed per country, the level of restriction in ASEAN countries tends to be greater when compared to trading partner countries (Japan, South Korea, and China). This is because ASEAN member countries have higher rates and higher non-tariff barriers and tariff differences in each of the relatively high ASEAN member countries on agricultural commodities. Indonesia as one of the countries that are willing to sign FTA should adhere to a more uncomplicated general RoO. Such a level of diagonal cumulation can further assist in regional integration and enable ASEAN member countries to share production factors so that production costs become cheaper. In the future, this cumulation can decrease the tendency of protection and trade diversion caused by RoO.

Furthermore, there is a need for more comprehensive rules of origin rule. Because $\mathrm{RoO}$ rules in Indonesia are still understood to be limited to technical regulations. So, that Indonesia has the potential to be harmed in trade in agricultural commodities within the framework of ASEAN + 1 FTA. Thus, it is necessary to harmonize procedures and trades that are no longer in the physical form to reduce administrative costs and documents. 


\section{References}

Anson, J., Cadot, O., Estevadeordal, A., de Melo, J., Suwa-Eisenmann, A. \& Tumurchudur, B. (2005). Rules of Origin in North-South Preferential Trading Arrangements with an Application to NAFTA. Review of International Economics. 13(3): 501-517.

Augier, P, Gasiorek, M \& Lai-Tong, C .(2005) . The Impact of Rules of Origin on Export. Economic Policy. 20 (43): 567-624.

Bourdon, M., Le Mouel, C., \& Peketi, M. (2016). The Impact of Regional Trade Agreements on Agrifood Ekspors : The Role of Rules of Origin. Working Paper SMART-LERECO N16-08 September 2016.

Cadot,Olivier., \& Yan Ing, L. (2014). How Restrictive Are ASEAN's RoO?. ERIA Discussion Paper. Series ERIA-DP-2014-18.

Cadot, O., Estevadeordal, A., \& Suwa-Eisenmann, A. (2005). 'RoO as Export Subsidies. CEPR Discussion Paper, No. 4999.

Chase, K. A. (2007). Industry Lobbying and RoO in Free Trade Agreements. Paper Proceding International Studies Association 48th Annual Convention, Chicago, Illinois, February 28-March 3.

Estevadeordal, A. \& Suominen, K. (2000). Measuring Rules of Origin in the World Trading System and Proposals for Multilateral Harmonization. Integration, Trade and Hemispheric Issues Division, Inter-American Development Bank.

Estevadeordal, A. \& Suominen, K. (2004). Rules of Origin: A World Map. In Cadot, O., Estevadeordal, A., Suwa-Eisenmann, A., \& Verdier, T. (eds). The Origin of Goods: A Conceptual and Empirical Assesment of Rules of Origin in PTAs. Washington: IADB and CEPR.

Estevadeordal, A. \& Suominen, K. (2005). What Are The Effects of Rules of Origin on Trade?. Mimeo, Integration and Regional Programs Department, Inter-American Development Bank.

Harris, J. (2007). Measurement and Determination of Rules or Origin in Preferential Trade Agreements (PTS's). (Unpublished Dissertation). College Park (USA): University of Maryland.

Kelleher, S. (2012). Playing by the Rules? The Development of an Amended Index to Measure the Impact of Rules of Origin on Intra-PTA Ekspors. UCD Centre for Economic Research Working Paper Series, WP12/22.

Manchin, M., \& Balaoing, A. (2007). Rules of Origin and the Web of East Asian Free Trade Agreements. World Bank Policy Research Working Paper 4273. Washington: World Bank.

Medalla, E. \& Balboa, J. (2009). ASEAN Rules of Origin: Lessons and Recommendations for Best Practice. ERIA Discussion Paper. Series 2009-17.

Tambunan, T. (2007). The Sub-regional Economic Cooperation Under the Framework of China-ASEAN Cooperation: The Case Study of Indonesian-China"Early Harvest Program”. Working Paper. Kadin Indonesia-Jetro. 


\section{Appendix}

(1) Coding Product Specific Rules of Origin

a. Coding based on legal text AJCEP agreements

\begin{tabular}{lcl}
\hline Section of HS & Position HS6 & Coding tipe RoO \\
\hline I. Live Animals & 1 & CC (1) \\
& 2 & CC exept from chapter 1 (1) \\
& 3 & CC (1) \\
& 4 & CC (1) \\
II. Vegetables & 5 & CC (1) \\
& 6 & CC (1) \\
& 7 & CC (1) \\
& 8 & CC (1) $(17)$ RVC (2) CTSH (4) \\
& 10 & CC (1) \\
& 11 & CC (8) CC except from chapter (4) \\
& 12 & CC (1) \\
13 & CC (1) \\
& 14 & CC (1) \\
\hline
\end{tabular}

b. Coding based on legal text AKFTA agreements

\begin{tabular}{lcl}
\hline Section of HS & Position HS6 & Coding tipe RoO \\
\hline III. Live Animals & 1 & WO (1) \\
& 2 & WO (2) \\
& 3 & WO (38) RVC (2) \\
& 4 & WO (13) CTSH (2) WO+RVC(2) \\
IV. Vegetables & 5 & WO (1) \\
& 6 & WO (1) \\
& 7 & WO (1) \\
& 8 & WO (27) \\
& 9 & WO (14) RVC (9) \\
& 10 & WO (1) \\
11 & WO (1) CTH (3) CTSH (9) \\
12 & WO (9) RVC (1) \\
13 & WO (1) \\
14 & WO (1) \\
\hline
\end{tabular}

c. Coding based on legal text ACFTA agreements

\begin{tabular}{|c|c|c|}
\hline Section of HS & Posisi HS6 & Coding tipe RoO \\
\hline \multirow[t]{5}{*}{ V. Live Animals } & 1 & $\mathrm{CC}(1)$ \\
\hline & 2 & $C C+R V C(2)$ \\
\hline & 3 & $\operatorname{RVC}(7)$ \\
\hline & 4 & RVC (19) \\
\hline & 5 & $\operatorname{RVC}(1)$ \\
\hline \multirow[t]{10}{*}{ VI. Vegetables } & 6 & $C C+R V C$ (1) \\
\hline & 7 & $C C+\operatorname{RVC}(1)$ \\
\hline & 8 & $C C+\operatorname{RVC}(1)$ \\
\hline & 9 & RVC (23) \\
\hline & 10 & RVC (14) \\
\hline & 11 & RVC (22) \\
\hline & 12 & RVC (57) \\
\hline & 13 & RVC (34) \\
\hline & 14 & $\operatorname{RVC}(48)$ \\
\hline & 15 & RVC (1) \\
\hline
\end{tabular}

Note: The numbers in brackets indicate how many times the rules of origin in the legal text are repeated 


\section{(2) Harris Restrictiveness index based on agriculture commodity}

a. Harris Restrictiveness index based on AJCEP agriculture commodity

\begin{tabular}{|c|c|c|}
\hline Regulation & Agricultural Sector (HS1-14) & Restrictiveness Index \\
\hline $\mathrm{CC}$ & 252 & 8 \\
\hline CC except from chapter 1 & 84 & 8 \\
\hline RVC (40) & 2 & 5 \\
\hline \multirow[t]{2}{*}{ CTSH } & 4 & 4 \\
\hline & $100 \%$ & 6,2 \\
\hline
\end{tabular}

b. Harris Restrictiveness index based on AKFTA agriculture commodity

\begin{tabular}{|c|c|c|}
\hline Regulation & Agricultural Sector (HS1-14) & Restrictiveness Index \\
\hline WO & 136 & 8 \\
\hline RVC (40) & 12 & 5 \\
\hline $\begin{array}{l}\text { WO from any ASEAN+1 FTA Party } \\
\text { or RVC (45) }\end{array}$ & 2 & 5 \\
\hline CTH + RVC (40) & 183 & $6+5$ \\
\hline \multirow[t]{2}{*}{$\mathrm{CTSH}$} & 9 & 4 \\
\hline & $100 \%$ & 6,6 \\
\hline
\end{tabular}

c. Harris Restrictiveness index based on ACFTA agriculture commodity

\begin{tabular}{|c|c|c|}
\hline Regulation & Agricultural Sector (HS1-14) & Restrictiveness Index \\
\hline $\mathrm{CC}$ & 1 & 8 \\
\hline$C C+\operatorname{RVC}(40)$ & 5 & $8+5$ \\
\hline \multirow[t]{2}{*}{ RVC (40) } & 226 & 5 \\
\hline & $100 \%$ & 8,6 \\
\hline
\end{tabular}

